\title{
VAS2870 is a pan-NADPH oxidase inhibitor
}

Citation for published version (APA):

Wingler, K., Altenhoefer, S. A., Kleikers, P. W. M., Radermacher, K. A., Kleinschnitz, C., \& Schmidt, H. H. H. W. (2012). VAS2870 is a pan-NADPH oxidase inhibitor. Cellular and Molecular Life Sciences, 69(18), 3159-3160. https://doi.org/10.1007/s00018-012-1107-1

Document status and date:

Published: 01/09/2012

DOI:

10.1007/s00018-012-1107-1

Document Version:

Publisher's PDF, also known as Version of record

\section{Document license:}

Taverne

\section{Please check the document version of this publication:}

- A submitted manuscript is the version of the article upon submission and before peer-review. There can be important differences between the submitted version and the official published version of record.

People interested in the research are advised to contact the author for the final version of the publication, or visit the DOI to the publisher's website.

- The final author version and the galley proof are versions of the publication after peer review.

- The final published version features the final layout of the paper including the volume, issue and page numbers.

Link to publication

\footnotetext{
General rights rights.

- You may freely distribute the URL identifying the publication in the public portal. please follow below link for the End User Agreement:

www.umlib.nl/taverne-license

Take down policy

If you believe that this document breaches copyright please contact us at:

repository@maastrichtuniversity.nl

providing details and we will investigate your claim.
}

Copyright and moral rights for the publications made accessible in the public portal are retained by the authors and/or other copyright owners and it is a condition of accessing publications that users recognise and abide by the legal requirements associated with these

- Users may download and print one copy of any publication from the public portal for the purpose of private study or research.

- You may not further distribute the material or use it for any profit-making activity or commercial gain

If the publication is distributed under the terms of Article $25 \mathrm{fa}$ of the Dutch Copyright Act, indicated by the "Taverne" license above, 


\title{
VAS2870 is a pan-NADPH oxidase inhibitor
}

\author{
Kirstin Wingler $\cdot$ Sebastian A. Altenhoefer • \\ Pamela W. M. Kleikers • Kim A. Radermacher • \\ Christoph Kleinschnitz $\cdot$ Harald H. H. W. Schmidt
}

Received: 14 June 2012/Revised: 23 July 2012/ Accepted: 23 July 2012/Published online: 9 August 2012

(C) Springer Basel AG 2012

In their detailed review "NADPH oxidases as therapeutic targets in ischemic stroke" [1], Kahles and Brandes discuss the pathological roles of NADPH oxidases in ischemic brain injury and the therapeutic implications. In agreement with the authors, we consider inhibition of NADPH oxidases as a promising strategy to treat ischemic stroke. As described in the review, we recently reported that NOX4-deficient mice are largely protected from brain damage caused by ischemic stroke, whereas we did not observe any effects by deleting NOX1 or NOX2. Thus, we believe that NOX4 is a highly promising target for stroke therapy. To further support our findings, we treated wildtype and NOX4 knockout mice with the NADPH oxidase inhibitor VAS2870 in a therapeutically relevant time window, i.e., post-stroke. Indeed, in wild-type mice, inhibition of NADPH oxidases by VAS2870 resulted in a similar degree of protection as did deletion of NOX4. In contrast, in NOX4 knockout mice, VAS2870 did not have any additional effects in reducing ischemic brain damage. This further supports our statement that NOX4, and not other

Comment on: NADPH oxidases as therapeutic targets in ischemic stroke. Timo Kahles, Ralf P. Brandes; 2012, doi:

10.1007/s00018-012-1011-8

K. Wingler $(\bowtie) \cdot$ S. A. Altenhoefer · P. W. M. Kleikers .

K. A. Radermacher - H. H. H. W. Schmidt

Department of Pharmacology and Cardiovascular Research Institute Maastricht (CARIM), Vascular Drug Discovery Group,

Faculty of Medicine, Health and Life Sciences,

Maastricht University, Universiteitssingel 50,

6229 ER Maastricht, The Netherlands

e-mail: k.wingler@maastrichtuniversity.nl

C. Kleinschnitz

Neurologische Klinik und Poliklinik, Universität Würzburg,

Würzburg, Germany
NOX isoforms, is the likely detrimental NOX isoform in ischemic stroke in mice. Unfortunately, to the best of our knowledge, there was and is no NOX4-selective inhibitor that could have been used to further support our findings.

Kahles and Brandes correctly describe that VAS2870 inhibits NOX1 and NOX2 and cite our relevant publications [2-4]. In the same issue of this journal, we provided evidence that VAS2870 also inhibits NOX4 [5]. In conclusion, we believe that VAS2870 is a pan-NOX inhibitor and not selective for any NOX isoform. However, in their review, Kahles and Brandes [1] state that we concluded that "VAS2870 was a Nox4-specific inhibitor based on the fact that the compound had no effect on the small infarcts they produced in Nox4 knockout mice". This is not true. We have never published such a statement on the NOX isoform-specificity of VAS2870. Both in the respective paper [6] and our other publications we describe VAS2870 as an NADPH oxidase inhibitor with no relevant specificity for any NOX isoform (data on NOX3 are not available) [5]. We have published similar data on the closely related derivative of VAS2870, VAS3947 [7]. Thus, we would kindly ask the authors to revoke their statement.

\section{References}

1. Kahles T, Brandes RP (2012) NADPH oxidases as therapeutic targets in ischemic stroke. Cell Mol Life Sci. doi:10.1007/s00018012-1011-8

2. Wingler K, Hermans JJR, Schiffers P, Moens AL, Paul M, Schmidt HH (2011) NOX1, 2, 4, 5: counting out oxidative stress. Br J Pharmacol 164:866-883. doi:10.1111/j.1476-5381.2011.01249.x

3. ten Freyhaus H, Huntgeburth M, Wingler K, Schnitker J, Baumer AT, Vantler M, Bekhite MM, Wartenberg M, Sauer H, Rosenkranz S (2006) Novel Nox inhibitor VAS2870 attenuates PDGF-dependent smooth muscle cell chemotaxis, but not proliferation. Cardiovasc Res 71:331-341. doi:10.1016/j.cardiores.2006.01.022 
4. Stielow C, Catar RA, Muller G, Wingler K, Scheurer P, Schmidt HH, Morawietz H (2006) Novel Nox inhibitor of oxLDL-induced reactive oxygen species formation in human endothelial cells. Biochem Biophys Res Commun 344:200-205. doi:10.1016/ j.bbrc.2006.03.114

5. Altenhöfer S, Kleikers P, Radermacher K, Scheurer P, Rob Hermans J, Schiffers P, Ho H, Wingler K, Schmidt H (2012) The NOX toolbox: validating the role of NADPH oxidases in physiology and disease. Cell Mol Life Sci. doi:10.1007/s00018012-1010-9

6. Kleinschnitz C, Grund H, Wingler K, Armitage ME, Jones E, Mittal M, Barit D, Schwarz T, Geis C, Kraft P, Barthel K,
Schuhmann MK, Herrmann AM, Meuth SG, Stoll G, Meurer S, Schrewe A, Becker L, Gailus-Durner V, Fuchs H, Klopstock T, de Angelis MH, Jandeleit-Dahm K, Shah AM, Weissmann N, Schmidt HH (2010) Post-stroke inhibition of induced NADPH oxidase type 4 prevents oxidative stress and neurodegeneration. PLoS Biol 8:e1000479. doi:10.1371/journal.pbio.1000479

7. Wind S, Beuerlein K, Eucker T, Muller H, Scheurer P, Armitage ME, Ho H, Schmidt HH, Wingler K (2010) Comparative pharmacology of chemically distinct NADPH oxidase inhibitors. $\mathrm{Br} \mathrm{J}$ Pharmacol 161:885-898. doi:10.1111/j.1476-5381.2010. 00920.x 